УДК 338.48

\title{
ЧИННИКИ РОЗВИТКУ СІЛЬСЬКОГО ЗЕЛЕНОГО ТУРИЗМУ В УКРАЇНІ
}

\section{FACTORS OF AGRICULTURAL GREEN TOURISM DEVELOPMENT IN UKRAINE}

\author{
Живко Зінаїда Богданівна \\ доктор економічних наук, профресор, \\ Львівський державний університет внутрішніх справ \\ ORCID: https://orcid.org/0000-0002-4045-669X \\ Боруцька Юлія Зіновіївна \\ кандидат геологічних наук, \\ Львівський національний аграрний університет \\ ORCID: https://orcid.org/0000-0002-5040-8624 \\ Рій Мирослава Михайлівна \\ викладач, здобувач, \\ Львівський державний університет внутрішніх справ \\ ORCID: https://orcid.org/0000-0001-5755-4598 \\ Zhyvko Zinaida \\ Lviv State University of Internal Affairs \\ Borutska Yuliia \\ Lviv National Agrarian University \\ Rii Myroslava \\ Lviv State University of Internal Affairs
}

\begin{abstract}
Стаття присвячена дослідженню сільського туризму як перспективної сорери діяльності на ринку туристичних послуг. Під час роботи над матеріалом стали дотичними до розгляду низки проблем пов'язаних з низьким рівне зайнятості сільського населення, нестачею робочих місць та найбільш вразила пасивність самої громади. Біорізноманіття природних ландшафтів, історична спадщина та культурно-демографрічний потенціал - це базис для розвитку сільського, екологічного та агротуризму. Сукупність трьох основних чинників сталого розвитку туризму у сільській місцевості може спонукати до реалізації наступних основних засад: природоохоронних (захист довкілля від деградації, контроль техногенного впливу у сільській місцевості); економічних (створення економічного мікроклімату у регіоні, розвиток промислового виробництва, створення робочих місць, стримування відтоку сільського населення); соціальних (забезпечення захисту і непорушності духовно-культурного та культурно-історичного розмаїття регіонів, сприятливого впливу туризму на різноманіття усталених звичаїв, традицій місцевої громади). Визначено основних споживачів послуг сільського зеленого туризму в Україні та мотивацію і визначальні фрактори щодо потреби відпочинку у сільській місцевості українських громадян.
\end{abstract}

Ключові слова: сільський туризм, традиції громади, захист довкілля від деградації, контроль техногенного впливу, екопросвітництво, екотуризм, громада.

Статья посвящена исследованию сельского туризма как перспективной сферы деятельности на рынке туристических услуг. Во время работы над материалом стали причастными к рассмотрению ряда проблем, связанных с низким уровнем занятости сельского населения, с нехваткой рабочих мест и наиболее поразила пассивность самой сельской общины. Биоразнообразия природных ландшафтов, историческое наследие и культурно-демографический потенциал - это базис для развития сельского, экологического и агротуризма. Совокупность трех основных фракторов устойчивого развития туризма в сельской местности может побудить к реализации следующих основных принципов: природоохранных (защита окружающей среды от деградации, контроль техногенного воздействия в сельской местности); экономических (создание экономического 
микроклимата в регионе, развитие промышленного производства, создание рабочих мест, сдерживание оттока сельского населения); социальных (обеспечение защиты и незыблемости духовно-культурного и культурно-исторического разнообразия регионов, благоприятное влияние туризма на многообразие сложившихся обычаев, традиций местной общины). Определены основные потребители услуг сельского туризма в Украине, мотивацию и факторы, определяющие необходимости отдыха в сельской местности украинских граждан.

Ключевые слова: сельский туризм, традиции общества, защита окружающей среды от деградации, контроль техногенного воздействия, экопросвещение, экотуризм, община.

The article is devoted to the study of rural tourism as a promising field of activity in the market of tourist services. During the work on the material, we became involved in the consideration of several issues associated with the low level of employment and unemployment of the rural population, the lack of jobs, and the passivity of the community itself. Biodiversity of natural landscapes, historical heritage, and cultural and demographic potential are the basis for the development of rural, ecological, and agro-tourism. The combination of three main factors for sustainable tourism development in rural areas can induce the implementation of the following basic principles: nature conservation (protection of the environment from degradation, control of man-made impacts in rural areas); economic (creating an economic microclimate in the region, developing industrial production, creating jobs, curbing the outflow of the rural population); social (provide protection and inviolability of the spiritual, cultural and historical diversity of the regions, the favourable influence of tourism on the diversity of established customs and traditions of the local community). A SWOT analysis of the direct and indirect factors of the development of rural green tourism (agro-tourism, agroecotourism) in Ukraine is carried out, the strengths and weaknesses, opportunities and threats of rural tourism are highlighted; new opportunities for territorial communities and local governments, taking into account the land reform; preservation of natural sites and restoration of historical and cultural sites. We consider the participation of communities in grants of the European Union, micro-projects competitions in the context of the development of rural areas as priority areas for the development of rural tourism; education and environmental education of tourists in the context of the development of eco-friendly forms of tourism in rural areas; education and enlightenment of tourists in the context of traditional culture, ethnography, customs, rituals and everyday life of a particular region; revival and development of forgotten cultural traditions and crafts. The main consumers of rural green tourism services in Ukraine and the motivation and determinants of the need for recreation in rural areas of Ukrainian citizens have been identified.

Keywords: rural tourism, community traditions, protection of the environment from degradation, control of technogenic impact, environmental education, ecotourism, community.

Постановка проблеми. В сучасних умовах господарювання, коли сільське населення не охоплене робочими місцями, незайнятість сільського населення дедалі більше спонукає робочу міграцію за кордон, що негативно впливає як на економічний, так і на соціальний розвиток України. А це своєю чергою впливає на необхідність розвитку таких галузей та сорер діяльності, які можуть розвиватися на територіях, де не задіяний в повній мірі людський потенціал. Саме розвиток туристичної сорери і сільського туризму, або як прийнято називати сільського (зеленого) туризму, як її складової, дасть можливість розвитку аграрних регіонів України, стане поштовхом диверсифікації сільської економіки. В умовах невизначеності та необхідності пошуку інноваційних шляхів розвитку сільських територій стимулювання і мотивування середнього та дрібного бізнесу в сільській місцевості, тобто сільського зеленого туризму особливо актуальне на потребує дослідження і розвитку.

Аналіз останніх досліджень. Особливості сільського туризму (в більшості наукових праць як сільського (зеленого) туризму) вітчизняними науковцями досліджувалися з позиції розвитку туристичної галузі і можливості залучення іноземних інвесторів. Чимало праць присвячено загалом туристичній галузі і сільському туризму виокремлюється незначна роль. Частина наукових досліджень зосереджено на вивченні і співставленні дефрініцій сільський (зелений) туризм (В. Биркович, О. Виноградова, В. Дарчук, В. Кифряк, Н. Кравченко, А. Сердюк, Н. Скрипник) та трактування поняття «сільський туризм» зарубіжними вченими (С. Кін, Дж. Лене, Р. Лобо, П. Нілсон). В працях В. Арнаутова, Ю. Боруцької, С. Ілляшенко, М. Костриця, К. Якуба та інших сільський зелений туризм розглянуто як перспективний напрямок туристичної сорери. Однак, інноваційні аспекти сільського (зеленого) туризму, перегляд в залежності від зміни навколишнього середовища та часового вектору, дослідження основних чинників сталого розвитку туризму у сільській місцевості наразі $€$ мало вивченим.

Формулювання цілей дослідження. Метою статті є визначення місця сільського (зеленого) туризму у системі «туризм - сільське господарство - екологізація свідомості», дослідження чинників розвитку сільського зеленого туризму в Україні.

Виклад основного матеріалу. Туристична сорера сьогодні важливим сектором економіки України. В українського сільського туризму $є$ усі об'єктивні передумови, аби стати візитівкою нашої держави на міжнародному турис- 
тичному ринку. Власне, саме це обґрунтовується бажанням, зокрема, іноземних туристів познайомитись 3 історично-культурним потенціалом і унікальним біорізноманіттям природних ландшасртів нашої країни. Водночас, украй гострою проблемою для багатьох сіл на часі $є$ низька зайнятість населення, пасивність громади, брак робочих місць, зростаючий надлишок робочої сили, вивільнюваної з сільськогосподарського виробництва. Саме тому, соціально-економічне відродження і майбутній розвиток сільських громад України усе більше пов'язують із туристичною індустрією, зокрема, сільського зеленого туризму (рис. 1).

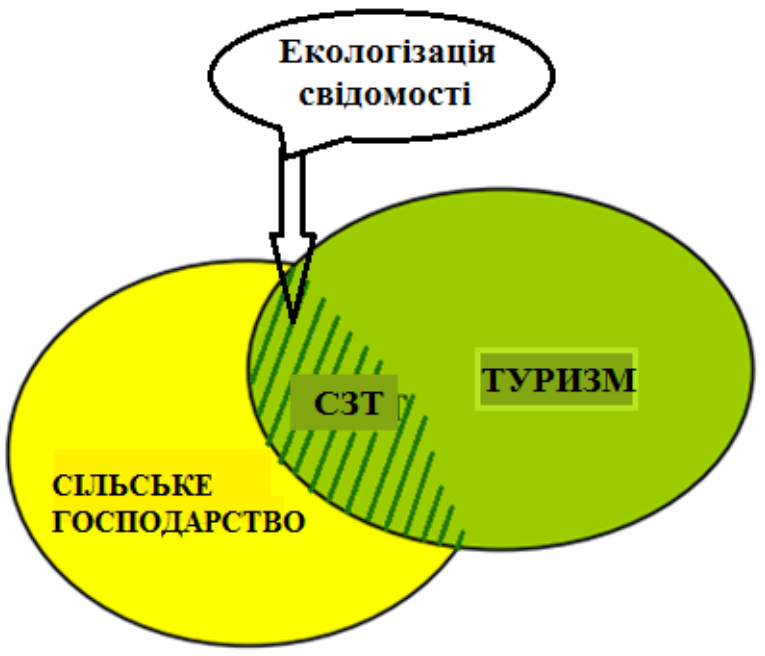

Рис. 1. Місце сільського зеленого туризму

у системі «туризм - сільське господарство екологізація свідомості»

Джерело: побудовано авторами

Головно, у громадянському суспільстві популяризацією цієї галузі займається «Спілка сприяння розвитку сільського зеленого туризму в Україні», осередки та відділення котрої діють у багатьох регіонах. Тому й, таким актуальним $€$ аналіз стану розвитку екологізованих форм туризму, зокрема сільського зеленого, агротуризму, агроекотуризму на теренах нашої держави.

Успішний розвиток сільського зеленого туризму можливий лише у випадку гармонійної взаємодії та взаємовпливу пріоритетів місцевого населення, туристів і навколишнього середовища. Баланс цих трьох чинників сталого розвитку туризму у сільській місцевості може гарантувати реалізація наступних основних засад (принципів) [1; 2; 3]: а) природоохоронних, які забезпечують захист довкілля від деградації, контролюється прийнятний техногенний вплив на у сільській місцевості; б) економічних, котрі сприяють економічному мікроклімату у регіоні, розвитку промислового виробництва, створенню робочих місць, стримуванню відтоку сільського населення в місто; в) соціальних, які гарантують захист і непорушність духовно-культурного та культурно-історичного розмаїття регіонів, та забезпечують сприятливий вплив туризму на різноманіття усталених звичаїв, традицій місцевої громади.

Урахування вище перелічених принципів актуальне під час регіонального планування розвитку сільського туризму і діяльності всіх суб'єктів: не тільки виробників туристичних послуг - садиб, різних візит-центрів, тематичних сільських парків, а й туристів, турагентств, державної влади й органів місцевого самоврядування [4]. Це гарантуватиме гармонійний, збалансований, ефективний розвиток сільського туризму за умови збереження та поваги до традицій і національної самобутності.

Прикро констатувати, проте, в Україні $€$ фрактори, котрі не тільки стимулюють розвиток сільського туризму, агротуризму, агроекотуризму, але й гальмують цей процес (табл. 1). Тільки обдумане й ефрективне залучення сильних сторін і можливостей, існуючих у нашій державі для розвитку сільського туризму, й уникнення передумов, сповільнюючих його еволюцію, сприятимуть і забезпечуватимуть успішність розвитку власної справи у цій сфрері діяльності [2; 5; 6].

Основними споживачами послуг сільського зеленого туризму в Україні є:

- міські жителі, сім'ї з дітьми, котрі головно проживають у квартирах багатоповерхівок, не маючи власних позаміських будинків, присадибних ділянок;

- люди пенсійного віку, які мають багато вільного часу та хочуть провести його наодинці чи, навпаки, з дітьми й онуками;

- учнівсько-студентська молодь, котрі використовують такий вид відпочинку, також, в еколого-освітніх, просвітницьких цілях;

- групи осіб, об'єднані спільними робочими стосунками або дозвіллям;

- люди, для яких це хобі (до прикладу, поєднання сільського туризму 3 окремими видами спорту) [7];

- іноземці, котрі приїжджають до України 3 пізнавальною, освітньою, культурною цілями;

- усі решту групи туристів, котрі мають індивідуальні уподобання щодо відпочинку у сільській місцевості.

Мотивацією та визначальними фракторами щодо потреби відпочинку у сільській місцевості в українських громадян є урбанізація, забруднення довкілля, відсутність коштів для відпочинку на дорогих курортах, відродження 
традицій, бажання побути ближче до природних умов (рис. 2). Свою прихильність щодо принципів екологізованих фрорм туризму, екосвідомість і відповідальність за стан навколишнього середовища та безпечне довкілля для майбутніх поколінь доволі нескладно декларувати через екопросвітницько-туристичну діяльність, використання продукції місцевих виробників, технічних ресурсів, залучення людських потенціалу цієї території. Тільки так можна зберігати та відроджувати автентичність екотуристичного продукту загалом. Водночас, це економічно-вигідно для цієї туристичної дестинації, жителів окремого населеного пункту, територіальної громади. Дуже вітається і вкладання коштів в освітню діяльність для навчання та майбутнього пра- цевлаштування місцевих мешканців, відтак зростає самозайнятість населення, особливо, сільських територій, зменшується ймовірність відтоку молоді у міста та з'являється фрінансова мотивація для додаткової зайнятості людей передпенсійного та пенсійного віку .

Висновки. Отож, зважаючи на те, що поступовий економічний розвиток і зростаючі темпи життя у містах подекуди негативно впливають як на фрізичний, так і на психоемоційний стан населення, у людей виникає логічне бажання відпочити у відмінних від звичного середовища умовах, трішки відмежуватися від зовнішнього світу, подихати свіжим повітрям, посмакувати органічними продуктами харчування, попити чистої води, побачити-почути щось нове та цікаве для власного розвитку.

Таблиця 1

SWOT-аналіз безпосередніх і опосередкованих чинників розвитку сільського зеленого туризму (агротуризму, агроекотуризму) в Україні

\begin{tabular}{|c|c|}
\hline Си & \\
\hline $\begin{array}{l}\text { - Україна - одна } \\
\text { - вигідне геограср } \\
\text { геополітичній кар } \\
\text { великих автомагіс } \\
\text { - велика площа д } \\
\text { - значна частка с } \\
\text { на яких потенційн } \\
\text { зелений туризм; } \\
\text { - багатий природ } \\
\text { розвинута мінера } \\
\text { - значний історик } \\
\text { потенціал; } \\
\text { - збережені від пр } \\
\text { особливо, у сільс } \\
\text { - багатство автен } \\
\text { навичок; } \\
\text { - активна діяльніс } \\
\text { агентств щодо ро } \\
\text { - створення гром } \\
\text { які займаютья }\end{array}$ & $\begin{array}{l}\text { - Пандемія Covid } 19 \text { (2020-2021 рр.); } \\
\text { - військовий конорлікт на сході України; } \\
\text { - відсутність зрозумілої нормативно- } \\
\text { правової бази щодо фрункціонування, } \\
\text { регулювання та надання послуг у сфері } \\
\text { СЗТ; } \\
\text { - не надто сприятливий візовий режим із } \\
\text { країнами Європейського Союзу; } \\
\text { - довготривалі катастросрічні наслідки, } \\
\text { спричинені аварією на Чорнобильській } \\
\text { атомній електростанції у квітні 1986 р.; } \\
\text { - відсутність державного забезпечення } \\
\text { та незадовільний стан об'єктів культурної } \\
\text { спадщини; } \\
\text { - часткова втрата окремих культурних } \\
\text { традицій і ремесел через відсутність } \\
\text { їхньої популяризації; } \\
\text { - низька якість і } \\
\text { неконкурентоспроможність послуг } \\
\text { транспортної та сервісної інфрраструктури } \\
\text { (особливо, поганий стан доріг); } \\
\text { - недостатній рівень розвитку комунікацій } \\
\text { у сільській місцевості; } \\
\text { - низька якість рекламно-інфрормаційного } \\
\text { контенту щодо популяризації } \\
\text { туристичного продукту на українському та } \\
\text { міжнародний ринках; } \\
\text { - недостатнє покриття та використання } \\
\text { можливостей інтернет-ресурсів; } \\
\text { - доволі низька якість обслуговування } \\
\text { туристів; } \\
\text { - невідповідність поміж ціновою } \\
\text { політикою й якістю надаваних послуг; } \\
\text { - низька соціальна свідомість і ділова } \\
\text { - активність населення. }\end{array}$ \\
\hline
\end{tabular}


(Закінчення таблиці 1)

\begin{tabular}{|c|c|}
\hline Можливості & Загрози \\
\hline 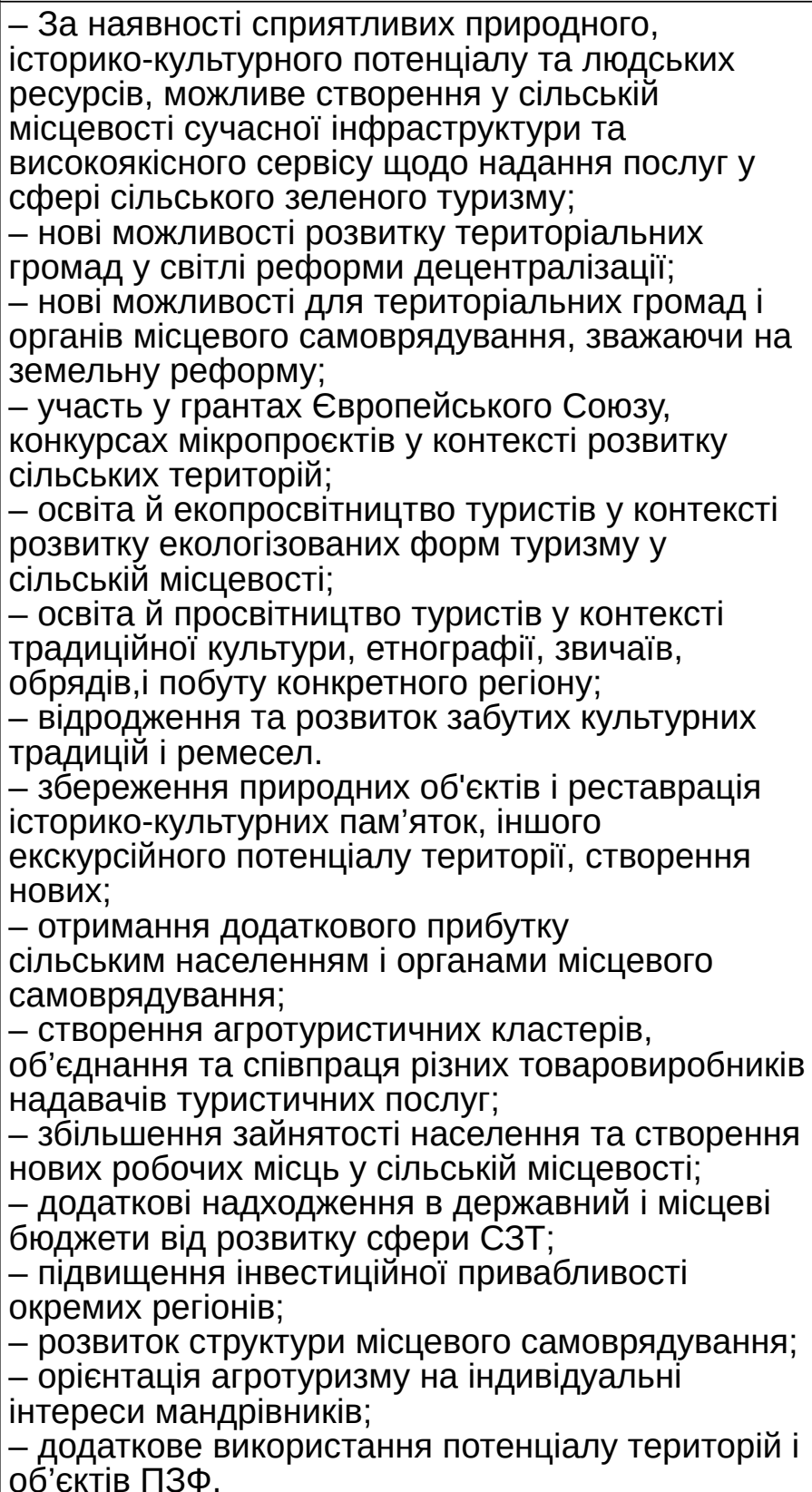 & $\begin{array}{l}\text { - Продовження карантинного періоду в } \\
\text { Україні та світі, спричиненого пандемією } \\
\text { Соvid-19 (2020-2021 рр.); } \\
\text { - продовження військового консрлікту на } \\
\text { сході України; } \\
\text { - небезпека посилення процесів } \\
\text { антропопресії на стан довкілля внаслідок } \\
\text { збільшення кількості туристів і рекреанті; } \\
\text { - відсутність чітких вимог у Законодавстві } \\
\text { України щодо масштабів надання послуг і } \\
\text { використання природних ресурсів у сфрері } \\
\text { СЗТ; } \\
\text { - обмаль фрінансування, скерованого на } \\
\text { реконструкцію екскурсійних об'єктів у } \\
\text { сільській місцевості; } \\
\text { - виїзд молоді та переважання жителів } \\
\text { похилого віку у сільській місцевості; } \\
\text { - відсутність фрінансової мотивації для } \\
\text { створення на сільських територіях } \\
\text { конкурентоспроможного бізнесу у ссрері } \\
\text { сільського туризму. }\end{array}$ \\
\hline
\end{tabular}

Джерело: складено авторами

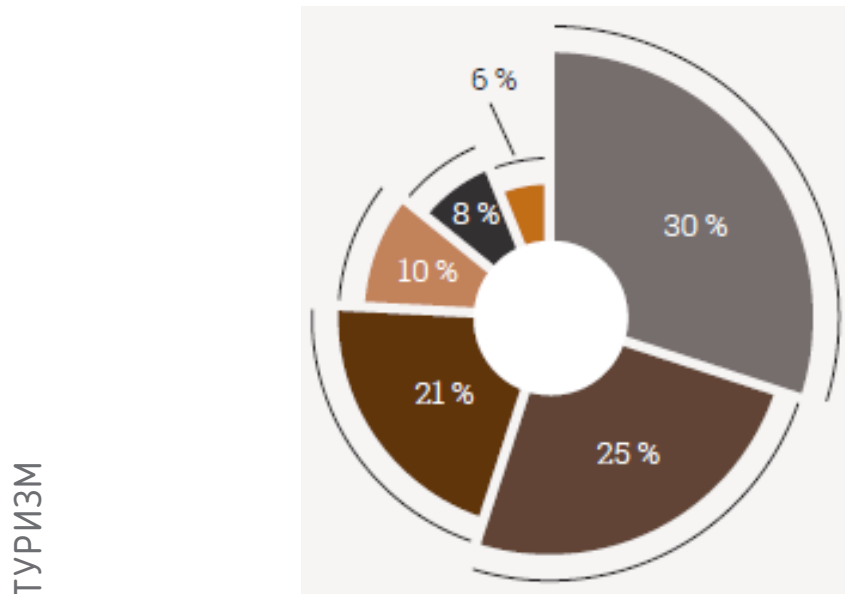

Урбанізація (30\%)

Забруднення довкілля (25\%)

Відсутність коштів для

відпочннку на дорогих курортах (21\%)

Звнчка відпочнватн

у сільській місцевості (10\%)

Залучення до траднцій

і звнчаїв ( $8 \%$ )

Блнзькість до

прнродного середовища (6\%) 
Іншим важливим фрактором $\epsilon$ те, що завдяки сільському зеленому туризму розвиваються малі підприємства, націлені на розвиток сільських територій. Виникають нові проєкти агротуризму, продуктового туризму, зеленого туризму віддалених територій, спортивного та оздоровчого туризму в сільських місцевостях. Встановлено співпрацю місцевих громад 3 туристичними фрірмами, результатом якої є проведення низки етнічних фрестивалів, конкурсів творчої самодіяльності, історичних маршрутів - стежками предків тощо.

Також, не менш вагомим стимулом $€ \mathrm{i}$ цінова політика. Усе-таки, у порівнянні, міські жителі вибирають відносно економніший вид відпочинку у поєднанні з бажанням побути віч-на-віч з природою.

\section{СПИСОК ВИКОРИСТАНИХ ДЖЕРЕЛ:}

1.Рибак С.Б., Боруцька Ю.З. Запровадження базових засад дуальної освіти в Екологічному коледжі Львівського HAY. Wschodnioeuropejskie Czasopismo Naukowe (East European Scientific Journal). Warsawa, Poland. 2017. Part 5(21). P. 8-14.

2.Бизнес в агро- и экотуризме : пособие / под общ. ред. А.И. Тарасенка. Минск, 2014. 380 с.

3. Боруцька Ю.З., Рибак С.Б. Порівняльна характеристика, аналіз і перспективи розвитку сільського зеленого туризму у різних регіонах України. Матеріали Круглого столу «Розвиток туризму в Україні: проблеми, виклики та перспективи», Львів, 26 вересня 2019 р. Львів : ЛНУВМтаБТ, 2019. С. 8-13.

4.Рудніченко Є.М., Гавловська Н.І., Живко 3.Б., Лісовський І.В. Теоретичний базис стратегічної адаптації системи менеджменту туристичних підприємств до трансформаційних процесів зовнішнього середовища. Вісник Хмельницького національного університету. 2020. № 6(288). С. 192-197.

5. Ткачук В.В. Проблеми інформаційно-аналітичного забезпечення розвитку сільського зеленого туризму. Науково-виробничий журнал «Інноваційна економіка». Тернопіль : СМП «ТАЙП», 2017. № 11-12 [72]. С. 156-160.

6. Ткачук В.В. Развитие сельского туризма в условиях децентрализации власти. Актуальные научные исследования в современном мире. Переяслав-Хмельницкий : ОО «Институт социальной транссрормации», 2018. Ч. 1-4 (33). С. 73-75.

7.Боруцька Ю.3. Світовий досвід методично-організаційних аспектів створення екологічних стежок. Екологія та природокористування в системі оптимізації відносин природи і суспільства : матеріали міжнародної науково-практичної консреренції. Львів : Екологічний коледж ЛНАУ, 2018. С. 26-30.

\section{REFERENCES:}

1. Rybak S.B., Borutska Yu.Z. (2017) Zaprovadzhennia bazovykh zasad dualnoi osvity v Ekolohichnomu koledzhi Lvivskoho NAU [Introduction of basic principles of dual education in the Ecological College of Lviv NAU]. Wschodnioeuropejskie Czasopismo Naukowe (East European Scientific Journal). Warsawa, Poland, part 5(21), pp. 8-14.

2. Byznes v ahro- y ekoturyzme: posobye (2014) [Business in agro- and ecotourism: a guide] / pod obshch. red. A.Y. Tarasenka. Mynsk, $380 \mathrm{p}$.

3. Borutska Yu.Z., Rybak S.B. (2019) Porivnialna kharakterystyka, analiz i perspektyvy rozvytku silskoho zelenoho turyzmu u riznykh rehionakh Ukrainy [Comparative characteristics, analysis and prospects of rural green tourism development in different regions of Ukraine]. Materialy Kruhloho stolu «Rozvytok turyzmu v Ukraini: problemy, vyklyky ta perspektyvy», Lviv, 26 veresnia 2019 r. Lviv: LNUVMtaBT, pp. 8-13.

4. Rudnichenko Ye.M., Havlovska N.I., Zhyvko Z.B., Lisovskyi I.V. (2020) Teoretychnyi bazys stratehichnoi adaptatsii systemy menedzhmentu turystychnykh pidpryiemstv do transformatsiinykh protsesiv zovnishnoho seredovyshcha [Theoretical basis of strategic adaptation of the management system of tourist enterprises to the transformation processes of the external environment]. Visnyk Khmelnytskoho natsionalnoho universytetu, no. 6(288), pp. 192-197.

5. Tkachuk V.V. (2017) Problemy informatsiino-analitychnoho zabezpechennia rozvytku silskoho zelenoho turyzmu. [Problems of information and analytical support for the development of rural green tourism]. Naukovo-vyrobnychyi zhurnal «Innovatsiina ekonomika». Ternopil: SMP «TAIP», no. 11-12[72], pp. 156-160.

6. Tkachuk V.V. (2018) Razvytye selskoho turyzma v uslovyiakh detsentralyzatsyy vlasty [Development of rural tourism in the context of power decentralization]. Aktualnye nauchnye yssledovanyia $v$ sovremennom myre. Pereiaslav-Khmelnytskyi: OO «Ynstytut sotsyalnoi transformatsyy», ch. 1-4 (33), pp. 73-75.

7. Borutska Yu.Z. (2018) Svitovyi dosvid metodychno-orhanizatsiinykh aspektiv stvorennia ekolohichnykh stezhok [World experience of methodological and organizational aspects of creating ecological trails]. Ekolohiia ta pryrodokorystuvannia $v$ systemi optymizatsii vidnosyn pryrody $i$ suspilstva: materialy mizhnarodnoi naukovo-praktychnoi konferentsii. Lviv: Ekolohichnyi koledzh LNAU, pp. 26-30. 